\title{
Manajemen Komunikasi Badan Lingkungan Hidup Kota Yogyakarta dalam Penanganan Limbah Perak di Kotagede
}

\author{
Oleh: Raditia Yudistira Sujanto, M.A
}

\begin{abstract}
Abstrak
Kesadaran akan bahaya limbah yang terdapat di dalam lingkungan tidak selalu dimiliki oleh semua lapisan masyarakat. Kesadaran tentunya tidak akan berguna tanpa adanya perbuatan dan perubahan. Kotagede merupakan daerah yang cukup terkenal dengan industri kerajinan peraknya. Dari pengerjaan kasar sampai penjualan hasil jadi kerajinan peraknya terdapat di Kotagede. Pada tahun 2004 BLH kota Yogyakarta mengadakan sosialisasi di Kotagede mengenai pentingnya menangani limbah perak secara benar dan efisien. Hal ini menjadi tanggung jawab BLH karena bagian dari tugas dan fungsi BLH dalam hal pelayanan publik.

Pada sosialisasi terakhir BLH gagal meyakinkan audiens sosialisasinya. Dengan dasar di atas peneliti melihat bagaimana manajemen komunikasi BLH dengan masyarakat Kotagede kaitannya dengan pembangunan kesadaran akan pentingnya penanganan limbah perak demi keselamatan dan kesehatan masyarakatnya sendiri serta lingkungan.

Penelitian ini dilakukan dengan pendekatan kualitatif eksploratoris dengan metode pengumpulan data yaitu wawancara serta studi dokumen. Metode penelitian sendiri adalah studi kasus. Penelitian ini menggunakan teori-teori dasar komunikasi dan manajemen, serta komunikasi krisis. Peneliti menilai bahwa terdapat krisis di dalam manajemen komunikasi BLH saat menjalankan program sosialisasinya. Penelitian ini menemukan bahwa terdapat beberapa hal yang memang menjadi kendala saat pembentukan program sosialisasi, dimulai dari tahapan 'perencanaan' sampai tahapan 'pengontrolan'.

Secara garis besar masalah -masalah yang sempat ada meliputi keputusan-keputusan tim pelaksana program dalam proses manajemennya yang tidak didasarkan pada pertimbanganpertimbangan budaya dan sosial sesuai dengan apa yang terdapat di Kotagede. Pada saat tahap 'pengorganisasian' pun tim pelaksana program tidak mempertimbangkan penugasan atas dasar kompetensi atau keahlian yang dimiliki anggota-anggotanya, melainkan atas dasar struktur jabatan atau organisasi. Terlebih lagi pada tahapan 'pengontrolan', tim pelaksana program tidak melakukan pelaporan dengan semestisnya, tidak melakukan pengarsipan, serta tidak melakukan pengawasan paska-program. Meskipun demikian, tidak sepenuhnya peneliti hanya menemukan hal-hal negatif atau kekurangan-kekurangan selama pelaksanaan penelitian. Melalui hasil temuan serta saran-saran yang peneliti lampirkan di akhir tesis ini, diharapkan BLH kembali melaksanakan program sosialisasi di Kotagede terkait masalah keberadaan bahaya limbah perak dan logam lainnya, karena peneliti tidak berharap BLH kecolongan waktu jika tindakan BLH di depannya nanti tidak lagi bersifat antisipatif melainkan reaktif terhadap kondisi lingkungan di daerah Kotagede.
\end{abstract}

Kata Kunci: manajemen komunikasi, limbah perak Kotagede, organisasi pemerintah, badan

\section{A. Pendahuluan}

Penelitian ini dimulai dari kenyataan bahwa program sosialisasi Badan Lingkungan Hidup (BLH) Kota Yogyakarta di Kotagede mengenai pentingnya mengelola limbah perak secara benar, yang dilaksanakan terakhir kali pada tahun 2004 silam. Tujuan dari program sosialisasi pada saat itu tidak tercapai. Sebagian masyarakat Kotagede yang menjadi audiens sosialisasi saat itu tidak menyetujui apa yang telah disampaikan dan disarankan 
Diterbitkan oleh Fakultas Sastra dan Budaya

Universitas Ahmad Dahlan Yogyakarta

oleh BLH. Konflik pun sempat terjadi dalam bentuk perlawanan seperti amarah yang meluap dari beberapa audiens (terutama dari pihak perusahaan perak besar). Salah satu alasan dari ketidaksetujuan audiens pada saat itu adalah kecurigaan mereka terhadap maksud sebenarnya dari rencana pelaksanaan perbaikan pengelolaan limbah itu sendiri, karena melibatkan sejumlah dana yang harus dikeluarkan oleh para pelaku industri perak di Kotagede. Dana yang bakal dikeluarkan sebenarnya relative kecil (sekitar Rp.1000000,-) dan bersifat komunal. Dana tersebut rencananya akan digunakan sebagai biaya tranportasi limbah terkumpul dari Kotagede sampai Kali Cileungsih di Jawa Barat. BLH sendiri berkontribusi dengan memberikan fasilitas truk pengangkut serta drum-drum penampung limbah cair di setiap pelaku pengrajin perak, terutama mereka yang melakukan kegiatan industrial seperti penyepuhan.

Melalui penelitian ini peneliti ingin mengetahui sebenarnya yang terjadi pada saat program sosialisasi pada waktu itu diadakan. Tidak hanya penelitian difokuskan pada saat hari pelaksanaan sosialisasi di lapangan, tapi penelitian lebih difokuskan pada keseluruhan kegiatan manajemen yang terdiri dari tahap perencanaan, pengorganisasian, pelaksanaan dan pengontrolan. Peneliti juga tetap memfokuskan penelitian pada bidang komunikasi, sehingga tidak melenceng ke bidang atau ilmu manajemen. Aspek-aspek komunikasi pun dilibatkan pada teori yang digunakan. Selain itu peneliti juga mengaitkan sedikit mengenai komunikasi krisis di dalam teori dan bahasannya. Dengan begitu melalui rumusan masalah dari penelitian ini peneliti ingin mengetahui bagaimana manajemen komunikasi BLH Kota Yogyakarta dalam penanganan limbah perak di Kotagede.

\section{B. Hasil Penelitian dan Pembahasan}

\section{BLH memandang masyarakat}

Secara umum nara sumber utama selaku ketua pelaksana program sosialisasi, Pieter Lawoasal menyebutkan bahwa terdapat tiga jenis masyarakat, yaitu (1) masyarakat tidak tahu, (2) masyarakat tahu tapi tidak bertindak, dan (3) masyarakat tahu dan bertindak. Peneliti pun bertanya masyarakat yang sempat menjadi audiens sosialisasi masuk ke jenis masyarakat yang mana dan mendapatkan jawaban bahwa mereka masuk ke jenis yang kedua (tahu tapi tidak bertindak). Kaitannya dengan penelitian ini, BLH melihat audiensnya sebagai masyarakat yang mengetahui keberadaan limbah perak cair di dalam air tanah dan beberapa sumur mereka tetapi tidak mau melakukan perubahan terhadap hal tersebut, terutama sekali bagi pelaku industri perak dalam hal penanganan limbah cairnya.

Peneliti turun ke masyarakat Kotagede dan bertanya apakah benar mereka tahu akan adanya keberadaan limbah perak di dalam air tanah atau bahkan sumur mereka. Peneliti mendapati hasil bahwa tidak semua mengetahui keberadaan limbahnya. Dengan begitu BLH terlalu "optimis" dengan praasumsinya.

\section{Akses Komunikasi yang Tersedia}

BLH sebenarnya menyediakan akses-akses yang memungkinkan masyarakat untuk dapat menyampaikan informasi atau bahkan berkomunikasi dengan BLH. Akses-akses yang ada meliputi mendatangi kantor BLH secara perorangan, mengirimkan surat ke kantor 
BLH, menggunakan fasilitas UPIK (unit pengaduan) yang disediakan pemerintah kota, menggunakan media radio, menggunakan surat kabar melalui surat pembaca, dan melalui situs resmi BLH.

Permasalah dari akses-akses tersebut di atas adalah ketidakefektifan dari hampir kesemua pilihannya. Yang dirasa paling efektif adalah mendatangi kantor BLH secara pribadi dan mengirimkan surat tertuju ke alamat kantornya. Akses lain dirasa tidak efektif, terutama sekali dari situs resmi BLH yang sebenarnya sekarang sudah tidak lagi tersedia. Pada saat peneliti melakukan penelitian di lapangan pada bulan Oktober 2013, situs remsi masih ada di dunia maya walaupun pada saat itu artikel terbaru yang dicantumkan dibuat pada tahun 2009. Dengan kata lain situsnya tidak diperhatikan seperti seharusnya. Saat ini situs yang bersangkutan sudah tidak lagi beredar.

\section{Keadaan Industri Perak di Kotagede}

Berdasarkan data yang diperoleh peneliti dari Koperasi Produksi Pengusaha Perak Yogyakarta (KP3Y) terdapat setidaknya 66 artshop yang terletak di Kotagede. Sebagian besar terletak di sepanjang Jl. Kemasan. Setelah peneliti melakukan penelitian sedikit lebih dalam mengenai keberadaan pelaku-pelaku bisnis perak di Kotagede, banyak yang ternyata belum terdaftar secara resmi di KP3Y dengan alasan bahwa tidak semua pengrajin perak merupakan pemilik perusahaan besar atau toko-toko resmi, karena banyak dari pengrajin yang membuka usaha rumahan dengan hanya memasang plang bertuliskan seperti "menerima pesanan perak".

Keberadaan industri perak bersifat rumahan ini tidak muncul tanpa alasan yang jelas. Sebelum bencana gempa bumi yang terjadi di Yogyakarta dan sekitarnya, terdapat sebuah museum bertajuk Living Museum Kerajinan Perak yang memprakarsai ide bahwa tidak selamanya para pengrajin perak hanya menyumbangkan hasil produksi mereka ke tangan-tangan perusahaan besar, tetapi mereka bisa menawarkan hasil produksi mereka langsung ke tangan pelanggan. Melalui usaha Living Museum tersebut, para pelancong yang mampir sering kali dibawa keliling ke daerah rumah-rumah warga yang bekerja sebagai pengrajin perak sehingga perhatian mereka tidak selalu hanya ke perusahaan atau toko perak yang besar.

\section{Keluhan Masyarakat Mengenai Limbah Perak}

Keluhan mengenai keberadaan limbah perak masuk ke telinga BLH ketika BLH mengadakan sosialisasi mengenai kali bersih. Memang tidak selamanya BLH mengandalkan timnya untuk mencari kasus atau masalah lingkungan yang perlu diperbaiki atau ditangani. Banyak kali BLH mengandalkan keaktifan dari masyarakat dalam bentuk keluhan-keluhan.

Keluhan mengenai limbah perak di Kotagede disampaikan dalam bentuk lisan ketika petugas BLH sedang melaksanakan sosialisasinya pada saat itu. Peneliti kemudian mencoba bertanya kepada salah seorang nara sumber bernama Agung, yang kebetulan juga seorang anggota senior Pemuda Muhammadiyah Kotagede, mengenai keluhan yang disampaikan secara lisan tersebut. Agung mengatakan bahwa karena sebagian masyarakat belum mengerti akses-akses yang tersedia bagi mereka untuk bisa berkomunikasi dengan 
Diterbitkan oleh Fakultas Sastra dan Budaya

Universitas Ahmad Dahlan Yogyakarta

BLH, mereka seakan-akan menunggu sampai ada kesempatan untuk bertemu langsung dengan petugas BLH.

\section{Pandangan BLH Mengenai Manajemen Komunikasi}

Peneliti menanyakan masalah pemahaman BLH mengenai manajemen komunikasi agar dapat terlihat apakah dalam proses pelaksanaan manajemennya sejak program sosialisasi dibentuk sudah memenuhi aspek-aspek komunikasi yang ada sebagai bahan pertimbangan. Berdasarkan wawancara yang dilakukan dengan Pieter Lawoasal selaku ketua pelaksana program sekaligus menjabat sebagai Kepala Subbidang Pemulihan Lingkungan Hidup BLH Kota Yogyakarta, apa yang dikatakan mengenai pengertian manajemen adalah menata apa yang simpang siur. Peneliti sedikit kurang setuju dengan pemahaman tersebut karena menurut teori dan pandangan peneliti pribadi, manajemen tidak hanya dilakukan ketika ada kesimpangsiuran, melainkan ketika keadaan stabil sekalipun. Manajemen bisa dilakukan sebagai bentuk antisipatif dan proaktif.

Pemahaman mengenai komunikasi pun turut ditanyakan peneliti kepada Pieter Lawoasal. Dikatakan bahwa komunikasi adalah kelancaran arus informasi. Ditambahkan, jika alur informasi lancar, komunikasi pun lancar. Dari pernyataan tersebut tidak ada yang perlu untuk tidak disetujui.

\section{Tahapan manajemen komunikasi program sosialisasi BLH}

Sesuai dengan tahapan manajemen yang ada, peneliti mengurutkan pembahasan mulai dari tahap perencanaan, pengorganisasian, pelaksanaan sampai pengontrolan.

\section{a. Tahap Perencanaan}

Secara umum yang dibahas dalam tahap ini adalah apa yang dilakukan oleh tim pelaksana program sosialisasi sebagai bentuk persiapan sebelum pelaksanaan sosialisasi dilaksanakan. Perencanaan meliputi pertimbangan-pertimbangan yang mendasari keputusan-keputusan yang diambil oleh tim pelaksana termasuk penentuan tujuan pesan, penentuan isi pesan, pertimbangan siapa yang menjadi pemberi pesan, saluran komunikasi yang dipilih, pertimbangan konteks budaya, waktu pelaksanaan sosialisasi, dan pertimbangan lingkungan lokasi yang akan digunakan.

Peneliti menemukan bahwa terdapat keputusan-keputusan selama tahap perencanaan yang diambil tidak berdasarkan pertimbangan yang tepat. Adapun nilai sosial dan budaya yang kurang dipertimbangkan secara matang dalam tahap awal manajemen ini. Pertimbangan sosial dan budaya yang kurang tepat ini mempengaruhi siapa yang akan duduk sebagai pembicara utama di meja panel pada saat sosialisasi. Peneliti menemukan bahwa pembicara utama atau penyampai materi sosialisasi dilakukan langsung oleh ketua pelaksana program sendiri yaitu Pieter Lawoasal. Bukan bermaksud untuk bersifat rasis tetapi peneliti berpendapat, sesuai dengan teori mengenai konteks budaya, ketika seseorang ingin menyampaikan pesan yang bersifat sensitif (masalah limbah perak selama ini merupakan topik yang cukup sensitif bagi kalangan pengusaha perak di Kotagede), pendekatan sosial dan budaya bisa sangat digunakan sebagai senjata awal. Setidaknya pengirim pesan atau penyampai materi sosialisasi ditentukan berdasarkan kedekatan budaya dengan audiens sosialisasi. 
Pengaruh termudah dari kedekatan budaya antara pengirim pesan dan penerima pesan adalah penggunaan bahasa yang sama; tidak hanya dari bahasa dan istilah yang digunakan, tetapi lelucon-lelucon lokal bisa membantu mencairkan suasanan yang tegang. Meski terkesan tidak seberapa penting, kedekatan budaya menjadi hal yang sangat vital ketika materi sensitif ingin disampaikan. Penggunaan intonasi atau aksen yang berbeda pun bisa mempengaruhi atmosfer di ruang sosialisasi.

Selain itu, pendekatan sosial dan budaya turut mempengaruhi keputusan tim pelaksana program dalam menentukan siapa yang turut diundang sebagai pendukung program di hari sosialisasi. Peneliti sempat menanyakan kepada seorang anggota senior Pemuda Muhammadiyah di Kotagede dan mendapatkan informasi bahwa di masyarakatnya terdapat beberapa tokoh masyarakat yang ditinggikan dan sangat dihormati. Tim pelaksana program tidak menggunakan keberadaan beberapa tokoh tersebut untuk dijadikan pendukung program sosialisasi. Peneliti berpendapat bahwa masyarakat akan lebih mendengarkan dan lebih tidak berani untuk tidak bersikap sungkan kepada tokoh-tokoh masyarakat yang ditinggikan di lingkup masyarakatnya. Pesan yang ingin disampaikan berupa pentingnya untuk mengelola limbah perak sehingga pencemaran air tanah tidak bertambah parah. Pesan sosialisasi bertujuan untuk menyelamatkan generasi sekarang dan mendatang masyarakat Kotagede sendiri, tanpa harus menghilangkan industri perak yang telah menjadi icon Kotagede. Dukungan dari tokoh penting masyarakat Kotagede kemungkinan besar akan memberikan dampak yang berbeda terhadap pencapaian tujuan program BLH tersebut.

\section{b. Tahap Pengorganisasian}

Dalam tahap ini yang ditekankan oleh peneliti adalah pertimbangan-pertimbangan apa yang menjadi dasar penugasan-penugasan anggota tim pelaksana program. Tahap pengorganisasian dalam ilmu dasar manajemen berpusat pada penugasan atau pemberian tanggung jawab. Peneliti mengaitkannya dengan aspek-aspek komunikasi yang ada.

Ketua pelaksana program sosialisasi secara otomatis menunjuk dirinya sendiri untuk menjadi pembicara utama pada saat pelaksanaan sosialisasi kelak. Pertimbangan yang ada atas penunjukkan dirinya adalah karena yang bersangkutan memiliki ilmu atau wawasan yang dirasa paling tinggi mengenai topik yang menjadi pembahasan di sosialisasi. Pieter Lawoasal telah bekerja di BLH selama puluhan tahun dan pengalaman di bidang lingkungan menjadikannya individu yang memiliki wawasan mengenai lingkungan serta pengelolaannya yang luas. Dasar itulah yang digunakan sebagai pertimbangan atas penunjukkan dirinya menjadi pembicara utama atau pemberi materi sosialisasi. Peneliti berpendapat bahwa tidak selamanya penguasaan materi yang sangat matang menjadikan seseorang seorang pembicara yang efektif. Secara praktis, di dalam ilmu humas pun dikatakan bahwa tidak selamanya seorang pimpinan perusahaan turun ke masyarakat untuk menjelaskan masalah atau menyampaikan pesan, karena sering kali seorang humas lah yang turun. Padahal secara tingkat pengetahuan mengenai perusahaannya, pimpinan perusahaan lebih memahami keadaan "kandangnya" sendiri. Jadi, menurut peneliti penugasan ketua pelaksana program dirasa kurang efektif karena ada pertimbangan lain yang lebih penting yaitu pertimbangan kesamaan budaya. Peneliti telah cukup menjelaskan masalah pentingnya budaya dan sosial di bagian tahap perencanaan di atas. 
Diterbitkan oleh Fakultas Sastra dan Budaya

Universitas Ahmad Dahlan Yogyakarta

Anggota-anggota lain yang menjadi bagian dari tim pelaksana program ditunjuk atau diberi tanggung jawab lebih karena berdasarkan struktur organisasinya. Tidak semua petugas ditugasi berdasarkan keahlian atau kemampuannya. Pieter sendiri sempat mengatakan bahwa sering kali petugas yang telah diberi tanggung jawab di rapat, ketika sudah di lapangan mereka tidak begitu mengerti sebenarnya harus melakukan tanggung jawab apa. Peneliti melihatnya sebagai kurangnya penegasan tanggung jawab pada saat rapat pemberian tugas dan kurangnya pemantauan kembali (crosscheck) atas apa yang sudah dimengerti dan yang belum dimengerti oleh petugas yang bersangkutan.

Selama tahap pengorganisasian kepala BLH tidak berperan besar. Kepala BLH hanya berperan saat kepala subbidang Pemulihan Lingkungan Hidup dipilih untuk menangani program sosialisasi yang bersangkutan.

Satu hal yang kurang dalam penugasan anggota tim pelaksana program adalah tidak adanya petugas yang ditunjuk sebagai notulen. Pembahasan ini akan lebih tepat dibahas di tahap manajemen selanjutnya.

\section{c. Tahap Pelaksanaan}

Dalam tahap pelaksanaan ini yang lebih dibahas berkisar masalah konflik yang sempat terjadi antara audiens sosialisasi dengan tim pelaksana program. Konflik yang dimaksud bukan berbentuk tindakan anarkis atau semacam itu melainkan dalam bentuk penolakan atas saran atau gagasan yang disampaikan oleh BLH melalui sosialisasinya. Pada intinya audiens menolak gagasan untuk melakukan pengelolaan limbah perak cair mereka. Audiens yang menolak sebagian besar adalah pengusaha perak. Kecurigaan mereka adalah dana yang akan digunakan untuk mengangkut limbah komunal akan disalahgunakan oleh BLH. Padahal dana yang diminta tidak banyak, sekitar satu juta rupiah untuk setiap pengangkutan limbah ke Kali Cileungsih dari Kotagede. Dana pun bersifat komunal, bukan per perusahaan.

Kecurigaan tim dari BLH adalah para pengusaha perak tidak mau bisnis mereka dikaitkan dengan keberadaan limbah di air tanah Kotagede. Para pengusaha menolak dan mengelak karena tidak ingin bisnis mereka disandungkan dengan masalah lingkungan yang bisa jadi akan berpengaruh pada bisnisnya. Padahal BLH tidak bermaksud untuk mematikan industri perak di Kotagede, melainkan hanya ingin limbah cairnya dikelola dengan benar dan bukannya diemisi ke saluran-saluran pembuangan rumah tangga biasa.

Selama sosialisasi dilakukan tidak ada yang bertugas sebagai notulen. Hal ini terkesan sederhana bagi tim pelaksana tetapi sebenarnya memiliki dampak yang cukup serius untuk ke depannya. Pada saat rapat evaluasi akan terlihat dampaknya. Lebih dari itu, dampak dari tidak adanya notulen akan terasa bahkan jauh setelah tim pelaksana program sosialisasi dibubarkan.

Kepala BLH tidak hadir di hari pelaksanaan sosialisasi dikarenakan yang bersangkutan takut. Dikatakan oleh Pieter bahwa kepala BLH tidak berani untuk hadir dikarenakan adanya atmosfer yang cukup panas yang berasal dari pihak audiens atau masyarakat. Padahal berdasarkan teori mengenai pola strategi komunikasi dan pelaksanaan fungsi manajemen, kepala atau top management memiliki aktivitas komunikasi yang sama dengan bagian middle dan bottom management yaitu 'pelaksanaan', yang berarti bahwa pelaksanaan turut dihadiri ketiga lapisan jabatan yang ada. 


\section{d. Tahap Pengontrolan}

Dalam tahap ini yang menjadi pembahasan utama ada evaluasi program, pengarsipan dan pengawasan pascaprogram. Pada rapat evaluasi program salah satu hal yang tentunya menjadi bahasan adalah ketidakberhasilan tim dalam pencapaian tujuan program dengan adanya penolakan dari audiens. Notulen sekali lagi tidak dihadirkan dalam rapat evaluasi.

Ketidakhadiran notulen dalam beberapa kesempatan selama pelaksanaan manajemen program sosialisasi berpengaruh pada kearsipan. Peneliti hampir tidak bisa mengakses bentuk laporan tertulis mengenai program yang dijalankan oleh tim pelaksana program. Laporan pun hanya berbentuk lisan kepada kepala BLH. Adapun bentuk laporan yang disampaikan kepada bidang Pelaporan, Data dan Administrasi berbentuk laporan anggaran. Sampai Oktober 2013 pada saat penelitian dilaksanakan, laporan anggarannya sudah tidak ada. Informasi dari kepala bidang Pelaporan, Data dan Administrasi ditemukan bahwa data atau arsip yang berusia lebih dari lima tahun akan otomatis dihilangkan.

Penghapusan arsip berusia lebih dari lima tahun dinilai peneliti sebagai tindakan yang tidak benar. Peneliti kemudian berbincang dengan kepala prodi jurusan Kearsipan dari Sekolah Vokasi UGM mengenai sistem kearsipan BLH yang ada dan didapatkan dari yang bersangkutan bahwa sistem seperti itu tidak benar. Seharusnya arsip tetap disimpan, terlebih lagi arsip program yang belum terselesaikan kasusnya, seperti kasus limbah perak di Kotagede ini.

Pengawasan dari subbidang Pengawasan Lingkungan Hidup pun tidak melakukan tugasnya dengan benar karena sejak dilaksanakan program sosialisasi pada tahun 2004 silam, pemantauan di lapangan tidak sempat dilakukan secara rutin. Adapun agenda pemantauan hanya difokuskan pada dua perusahaan perak di Kotagede yang selalu sama setiap tahunnya (demi formalitas pekerjaan). Hasil dari laboratorium pun sejak bulan April 2013 belum keluar sampai Oktober 2013, padahal hasil bisa keluar maksimal dalam hitungan 10 hari sejak dimasukkan ke dalam laboratorium.

e. Komunikasi krisis manajemen komunikasi program sosialisasi BLH

Penelitian mengenai komunikasi krisis dalam manajemen komunikasi program sosialisasi BLH mendapatkan bahwa tim pelaksana program tidak selalu menyadari keberadaan krisis sebelum program sosialisasi disusun. Kurangnya kesadaran akan keberadaan krisis memang menjadi hal yang krusial karena dampak akan terus terjadi selama program dilaksanakan. Hal tersebut dapat terjadi karena kesadaran akan keberadaan krisis berpotensi besar dalam menjadikannya bahan pertimbangan keputusan yang diambil.

Sebelum dilaksanakannya program, tim pelaksana program kurang menyadari adanya tingkat kepercayaan publik (Kotagede) terhadap kinerja BLH selama ini. Peneliti sempat berbincang dengan beberapa staf di kantor kelurahan Purbayan Kotagede dan mendapatkan informasi bahwa mereka (masyarakat) tidak begitu percaya dengan program BLH karena pada program-program sebelumnya BLH tidak melakukan programnya dengan sepenuhnya. Satu contoh yang sempat dijelaskan adalah program kompos. Program kompos sempat dijalankan oleh BLH, yang melibatkan beberapa perlengkapan (seperti mesin kompos) yang diberi oleh BLH. Setelah sosialisasi mengenai cara penggunaan mesin kompos, BLH tidak lagi mengecek atau melakukan pemantauan pascaprogram. Banyak 
Diterbitkan oleh Fakultas Sastra dan Budaya

Universitas Ahmad Dahlan Yogyakarta

mesin kompos yang sebenarnya tidak sempat digunakan oleh warga dan BLH tidak melakukan pengecekan terhadapnya.

Peneliti berpendapat bahwa hal mendasar yang menjadi persoalan dalam ketidakberhasilan program sosialisasi tahun 2004 silam adalah rendahnya tingkat kepercayaan masyarakat terhadap BLH secara umum. Krisis kepercayaan tersebut yang seharusnya diperbaiki dari awal sebelum program mulai disusun.

\section{Kesimpulan}

Kesimpulan yang dapat ditarik dari pembahasan di atas adalah:

1. BLH tidak atau kurang menyadari krisis kepercayaan yang ada dari masyarakat Kotagede. Masalah ini seharusnya sudah diketahui oleh BLH sebelum program sosialisasi mulai disusun. Dampak yang sangat jelas dari rendahnya tingkat kepercayaan tersebut adalah pertimbangan-pertimbangan yang kurang tepat selama tim pelaksana program menjalankan manajemen komunikasi mulai dari tahap pelaksanaan sampai tahap pengontrolan.

2. Penelitian sosial dan budaya tidak sempat dilakukan oleh tim pelaksana untuk membantu membaca keadaan atau situasi di Kotagede. Hal ini berpengaruh juga terhadap pertimbangan pemilihan atau penentuan siapa yang menjadi pemberi pesan, penerima pesan, pendukung sosialisasi, serta beberapa hal lainnya.

3. Tim pelaksana program kurang memberikan penegasan terhadap tugas-tugas dan tanggung jawab yang diberikan kepada setiap anggotanya. Absensi notulen di saat pelaksanaan dan beberapa rapat manajemen menjadi satu hal kecil yang berdampak sangat besar. Notulen yang nihil mengakibatkan tim pelaksana program tidak dapat mengingat secara rinci mengenai hal-hal yang terjadi, pada saat pelaksanaan rapat evaluasi. Selain itu nihilnya notulen tentunya mengakibatkan kesulitan penyusunan program sosialisasi lanjutan ke depannya karena arsip dari notulen seharusnya dapat dijadikan bahan pembelajaran bagi tim pelaksana program lanjutannya.

4. Sistem kearsipan merupakan bagian dari komunikasi dan itu tidak dijalankan dengan benar oleh BLH. Obrolan peneliti dengan Pieter Lawoasal mendapatkan bahwa sebenarnya ada dua jenis kasus besar yang bisa dilihat. Peneliti menilai ada kasus yang belum selesai da nada kasus yang sudah diselesaikan. Sistem kearsipan di BLH tidak mendukung hal tersebut karena arsip yang sudah berusia lima tahun lebih akan dihanguskan, meski kasusnya belum terselesaikan. Kasus mengenai keberadaan limbah perak di Kotagede merupakan kasus yang belum terselesaikan, setidaknya menurut pandangan peneliti sendiri -dikarenakan pada sosialisasi terakhir tim pelaksana program tidak berhasil mencapai tujuan program yang ada.

5. Pilihan akses-akses yang disediakan oleh BLH yang dapat memungkinkan masyarakat untuk berkomunikasi dengan BLH tidak berjalan dengan efektif. Salah satu akses komunikasi yaitu situs resmi BLH saat ini sudah tidak beroperasi lagi. Peneliti berbincang dengan beberapa warga di Kotagede dan mereka mengaku tidak begitu tahu pilihan-pilihan akses komunikasi yang ada jika mereka harus melaporkan sesuatu ke BLH. 


\section{Referensi}

Pustaka:

Rudi, T. May. 2005. Komunikasi dan Humas Internasional. Bandung: PT Refika Aditama.

Hynes, Geraldine E. 2005. Managerial Communication Strategies and Applications. Singapore:

McGraw-Hill Education (Asia).

Ruslan, Rosady. 1999. Manajemen Humas dan Manajemen Komunikasi Konsepsi dan Aplikasi.

Jakarta: Raja Grafindo Persada.

Dwidjowijoto, Riant Nugroho. 2004. Komunikasi Pemerintahan. Jakarta: PT Elex Media Komputindo.

Salam, Dharma Setyawan. 2007. Manajemen Pemerintah Indonesia. Jakarta: Djambatan. 